\title{
\begin{tabular}{cc|c|} 
Jurnal Abdimas Saintika & $\begin{array}{l}\text { e-ISSN : 2715-4424 } \\
\text { p-ISSN :2746-797X }\end{array}$ \\
\hline Volume 3 Nomor $1 \mid$ https://jurnal.syedzasaintika.ac.id &
\end{tabular}
}

\section{UPAYA MENINGKATKAN KESADARAN MENCUCI TANGAN DI DESA SIKAPAK BARAT KECAMATAN PARIAMAN UTARA KOTA PARIAMAN}

\author{
Marisa Lia Anggraini1 ${ }^{*}$, Fanny Jesica ${ }^{2}$, Ade Nurhasanah Amir ${ }^{3}$ \\ Program Studi S1 Kebidanan, Stikes Syedza Saintika \\ *Email : marisaliaanggraini@gmail.com
}

\begin{abstract}
ABSTRAK
Mencuci tangan merupakan satu hal yang penting dilakukan dalam kehidupan sehari-hari untuk tetap menjaga kebersihan. Tujuan dari pelaksanaan pengabdian masyarakat ini adalah untuk memberikan informasi kepada masyarakat dan stakeholder yang ada dalam lingkungan di desa sikapak barat dalam hal cuci tangan yang baik dan benar. Metode pelaksanaan dari pengabdian ini adalah sosialisasi, pengetahuan dan demonstrasi, serta evaluasi. Sosialisasi dimulai dari koordinasi bersama Kepala Desa Sikapak Barat, Ketua RT/ RW, dan kepada kepala keluarga setiap masyarakat untuk mengadakan kegiatan di Desa Sikapak Barat. Pengetahuan dan demonstrasi dimulai dari pembagian leaflet emudian memberikan informasi teknik cuci tangan yang benar dan waktu cuci tangan yang baik, serta selanjutnya mencontohkan cara mencuci tangan yang baik dan benar. Setelah itu melakukan monitoring dan evaluasi. Ditemukan bahwa warga mulai perlahan mengalami perubahan kebiasaan, dimana warga selalu mencuci tangan setiap sebelum dan sesudah masuk rumah/ termpat tertentu dan sebelum makan sesuatu. Selain itu teknik cuci tangan yang dilakukan sudah sesuai dengan anjuran WHO. Kesimpulannya bahwa pelaksanaan pengabdian masyarakat ini efektif dilakukan untuk mengubah kebiasaan masyarakat dan perilaku masyarakat untuk melakukan cuci tangan yang baik dan benar.
\end{abstract}

Kata kunci: cuci tangan, kesadaran, masyarakat

\section{ABSTRACT}

Washing hands is an important thing to do in everyday life to maintain cleanliness. The purpose of implementing this community service is to provide information to the community and stakeholders in the environment in the village of West Sikapak in terms of proper and correct hand washing. The implementation method of this service is socialization, knowledge and demonstration, and evaluation. The socialization started with coordination with the Head of the Village of West Sikapak, the Head of the $R T / R W$, and to the head of the family of each community to hold activities in the Village of West Sikapak. The knowledge and demonstration starts with the distribution of leaflets, then provides information on proper hand washing techniques and proper hand washing times, and then exemplifies how to wash hands properly. After that, conduct monitoring and evaluation. It was found that residents began to slowly change their habits, where residents always wash their hands before and after entering a certain house / place and before eating something. In addition, the hand washing technique that is carried out is in accordance with WHO recommendations. The conclusion is that the implementation of this community service is effective in changing people's habits and people's behavior to do good and correct hand washing.

Key words: hand washing, awareness, community 


\section{Jurnal Abdimas Saintika}

PENDAHULUAN

Pelaksanaan pembangunan dalam bidang kesehatan dengan memberikan prioritas pada upaya peningkatan kesehatan, pencegahan penyakit dengan tidak mengabaikan upaya penyembuhan dan pemulihan kesehatan, termasuk kepada anak usia Sekolah Dasar demi tercapainya derajat kesehatan yang optimal. Adapaun usaha untuk menunjang upaya kesehatan yang optimal maka upaya di bidang kesehatan yaitu kebiasaan mencuci tangan sebelum dan sesudah makan perlu mendapat perhatian (Rismawati, 2012).

Gerakan pola hidup sehat di masyarakat sedang ditingkatkan melalui berbagai program yang dijalankan oleh pemerintah. Menurut Kementerian Kesehatan RI (2014), kondisi sehat dapat dicapai dengan mengubah perilaku dari tidak sehat menjadi perilaku sehat dan menciptakan lingkungan sehat. Program tersebut dinamakan Perilaku Hidup Bersih dan Sehat (PHBS). PHBS ini masih belum dipahami oleh masyarakat karena kurangnya informasi yang diterima dan juga kurangnya dukungan fasilitas untuk program tersebut (Hadiyanto, 2016). Kegiatan PHBS salah satunya dengan tindakan Cuci Tangan Pakai Sabun (CTPS).

Perilaku sehat cuci tangan pakai sabun yang merupakan salah satu kebiasaan pola hidup bersih dan sehat (PHBS). Banyak program cuci tangan yang menyasar siswa sekolah dasar karena kebanyakan anak pada masa sekolah dasar berperilaku cuci tangan yang tidak sesuai anjuran dengan menggunakan 6 langkah. Anjuran WHO terkait dengan cuci tangan menggunakan teknik 6 langkah dan waktu cuci tangan sesuai dengan 5 moment (WHO, 2009). Hal yang sering terjadi pada anak-anak seperti mencuci tangan tidak menggunakan sabun dan tidak di air mengalir. Padahal aktifitas mereka kebanyakan menggunakan tangan. Kesehatan pada anak sekolah menjadi salah satu dasar untuk melihat sejauh mana derajat kesehatan pada anak. Permasalahan perilaku kesehatan pada anak usia sekolah dasar sangat banyak namun yang lebih sering menjadi masalah akibat perilaku hidup sehat yang kurang baik salah satunya adalah diare. Sebanyak 6 juta anak meninggal setiap tahunnya karena diare pada Negara berkembang. Diperkirakan lebih dari 10 juta anak berusia kurang dari 5 tahun sekitar 20\% meninggal karena infeksi diare (Kemenkes, 2011).

Mencuci tangan merupakan salah satu perilaku pencegahan penyakit. Hal ini dilakukan karena tangan sering membawa kuman pathogen seperti Escherichia Coli atau Sigela berpindah dari satu orang ke orang lain melalui makanan atau perilaku yang tidak bersih (Departemen Kesehatan RI, 2011). Menurut WHO Tahun 2013 diare merupakan penyakit kedua yang menyebabkan kematian pada anak. Diare menurun $45 \%$ dengan berperilaku mencuci tangan memakai sabun kemudian jika $32 \%$ masyarakat meningkatkan akses terhadap sanitasi dasar dan 39\% pengolahan minum rumah tangga maka hal ini dapat menurunkan kejadian diare sebanyak 94\% (RI, 2007). Perilaku cuci tangan dengan kejadian diare sangat berhubungan. Jika perilaku anak suka mencuci tangan maka kejadian diare sangat kecil begitu sebaliknya (Enikmawati \& Hidayatul, 2017). Pendidikan kesehatan dapat merubah perilaku cuci tangan siswa menjadi baik dan benar (Susilaningsih \& Hadiatama, 2013)

Personal hygiene merupakan perawatan diri sendiri yang dilakukan untuk mempertahankan kesehatan baik secara fisik maupun psikologis (Ambarwati dkk, 2009). 


\section{Jurnal Abdimas Saintika}

Volume 3 Nomor $1 \mid$ https://jurnal.syedzasaintika.ac.id

Salah satu cara personal hygiene yaitu dengan mencuci tangan menggunakan sabun dan air mengalir (Siswanto, 2010).

Mencuci tangan dengan menggunakan sabun terbukti secara ilmiah efektif untuk mencegah penyebaran penyakit-penyakit menular seperti diare, Infeksi Saluran Pernapasan Atas (ISPA) dan Flu Burung. Sebagaimana diketahui bahwa mencuci tangan dalam kehidupan sehari-hari sangat penting, contohnya setelah buang air dan sebelum memegang makanan. Cuci tangan sangat berperan dalam membantu mengurangi risiko terkena diare lebih dari $40 \%$ dan infeksi saluran pernapasan hampir 25\%(Depkes, 2010).

Kebersihan merupakan hal vital bagi terwujudnya masyarakat yang sehat. Kebersihan dan kesehatan sangat berpengaruh pada kondisi fisik dan psikis seseorang. Kebersihan dipengaruhi oleh faktor individu dan kebiasaan (Kementrian Kesehatan RI, 2012). Namun, kebersihan seringkali diabaikan oleh masyarakat, karena kebersihan dianggap sesuatu yang sepele dan tidak begitu penting. Setyaningrum (2015) menjelaskan bahwa kebersihan ini perlu ditanamkan sejak dini kepada anak-anak agar kebersihan dapat menjadi suatu keharusan dan kebiasaan positif. Anakanak perlu diajarkan bagaimana menjaga kebersihan mulai dari hal kecil, agar terhindar dari berbagai jenis penyakit. Kebiasaan tidak mencuci tangan berpotensi untuk mengundang berbagai penyakit seperti diare (Listiyorini, 2012; Utomo et.al, 2015; Setyaningrum et.al, 2016) dan cacingan (Sillitonga et.al, 2009; Winita et.al, 2012).

Hasil penelitian yang dilakukan oleh Luby, dkk (2009) membuktikan bahwa dengan cuci tangan pakai sabun secara konsisten dapat mengurangi diare dan penyakit pernafasan. CTPS dapat mengurangi diare sebanyak $31 \%$ dan menurunkan penyakit ISPA sebanyak $21 \%$. Riset global juga menunjukkan Jurnal Abdimas Saintika bahwa kebiasaan CTPS tidak hanya mengurangi, tetapi mencegah kejadian diare hingga $50 \%$ dan ISPA hingga $45 \%$ (Fazriyati, 2013).

Kesadaran pola hidup sehat dan bersih khususnya CTPS hingga saat ini belum menjadi kebiasaan dan kewajiban yang harus dilakukan anak setelah melakukan aktivitas. Meskipun hal ini terlihat sederhana, tetapi para orang tua belum memahami dan mempraktekkan secara benar dalam kehidupan rumah tangga sebagaisuatu kewajiban dan harus dilakukan untuk menjaga kesehatan (Fitriasari dan Syaifudin, 2011). Sosialisasi sangat penting diberikan pada anak usia 3-5 tahun. Sosialisasi kebiasaan cuci tangan dapat dilakukan dengan (1) menjelaskan pentingnya cuci tangan pakai sabun; (2) mencuci tangan sambil bernyanyi; (4) meletakkan wastafel di tempat yang terjangkau oleh anak dan (5) selalu mengingatkan dan mengawasi anak untuk hidup bersih. Pentingnya membersihkan tangan inilah yang kemudian membuat tenaga kesehatan memberikan penyuluhan kesehatan melalui beberapa media seperti ceramah, media video, menyanyi dan menggunakan gambar (Depkes RI, 2009).

Berdasarkan latar belakang dan permasalahan di atas, maka penulis tertarik melakukan pengabdian kepada masyarakat melalui "Upaya Meningkatkan Kesadaran Mencuci Tangan di Desa Sikapak, Kecamatan Pariaman Utara, Kota Pariaman." Kegiatan ini bertujuan untuk meningkatkan pengetahuan tentang teknik mencuci tangan pakai sabun yang benar, meningkatkan ketrampilan dan kebiasaan masyarakat tentang mencuci tangan setelah melakukan aktivitas di tempat-tempat umum maupun di rumah, serta meningkatkan kesadaran masyarakat agar menjaga kebersihan diri (personal hygiene). Adapun manfaat dari 


\section{Jurnal Abdimas Saintika}

Volume 3 Nomor 1 | https://jurnal.syedzasaintika.ac.id

kegiatan ini adalah mahasiswa di desa sikapak dapat mengetahui dan mempraktekkan teknik cara mencuci tangan dengan baik dan benar serta terampil dan memiliki kebiasaan untuk mencuci tangan pakai sabun sebelum dan sesudah melakukan aktivitas di tempattempat umum maupun di rumah.

\section{METODE PENGABDIAN}

\section{Waktu dan Tempat}

Waktu pelaksanaan kegiatan pengabdian kepada masyarakat ini yaitu tanggal 3-4 April 2021. Lokasi dilakukan kegiatan ini adalah di Kantor Desa Sikapak Barat, Kecamatan Pariaman Utara, Kota Pariaman.

\section{Metode dan Rancangan Penelitian}

Metode yang digunakan dalam pelaksanaan pengabdian ini adalah metode ceramah, memberikan leaftlet dengan tujuan memberikan wawasan tentang cara mencuci tangan yang benar. Rancangan pengabdian ini yaitu : (1) Tahap sosialisasi program: Pada tahap ini sosialisasi dilakukan dengan koordinasi bersama Kepala Desa Sikapak Barat, Ketua RT/ RW, dan kepada kepala keluarga setiap masyarakat untuk mengadakan kegiatan di Desa Sikapak Barat, Kecamatan Pariaman Utara, Kota Pariaman. Kegiatan ini diperkenalkan kepada seluruh masyarakat di Desa Sikapak Barat. Sosialisasi ini sangat efektif dalam menciptakan komunikasi yang baik antara tim pelaksana dan Kepada Desa, Ketua RT/ RW, kepala keluarga, dan seluruh masyarakat di Desa Sikapak Barat, sehingga kegiatan diharapkan berjalan lancar. (2) Tahap Pengetahuan dan Demonstrasi : Tahap Pengetahuan dan Demonstrasi dilakukan yaitu dengan penyuluhan teknik mencuci tangan denganbaik dan benar dan cara edukasi mencuci tangan yang baik dan benar. Setelah tahap Pengetahuan dan demonstrasi ini, masyarakat dapat mengetahui dan mempraktekkan teknik dan cara mencuci tangan yang baik dan benar, serta terampil dan memiliki kebiasaan untuk mencuci tangan pakai sabun sebelum dan sesudah melakukan aktivitas di kantor, di rumah, atau dimanapun berada. (3) Evaluasi Kegiatan : Untuk mengetahui keberhasilan dari kegiatan ini, maka dilakukan evaluasi dengan tujuan untuk mengetahui tingkat pengetahuan dari mitra pengabdian. Parameter keberhasilan kegiatan pengabdian ini adalah meningkatnya pengetahuan mitra mengenai teknik mencuci tangan yang baik dan benar. Evaluasi kegiatan ini dilaksanakan dengan memberikan kuesioner di awal (pretest) dan diakhir (posttest) kegiatan pengabdian. Kuesioner yang diberikan berisi pertanyaan-pertanyaan terkait materi yang disampaikan pada kegiatan pengabdian. Jika skor posttest peserta yang dihasilkan lebih baik dari pretest, maka hal tersebut mengidentifikasikan jika kegiatan pengabdian ini telah berhasil meningkatkan pengetahuan mitra tentang cara mencuci tangan yang baik dan benar (Sariwati, dkk., 2019; Shofi, 2019).

\section{HASIL DAN PEMBAHASAN}

Pelaksanaan program pengabdian kepada masyarakat dilaksanakan di Desa Sikapak Barat, Kecamatan Pariaman Utara, Kota Pariaman pada tanggal 3-4 April 2021 berjalan dengan baik dan lancar. Pengabdian kepada masyarakat ini diikuti oleh Kepala Desa Sikapak Barat, kepala RT/ RW di Desa Sikapak Barat, dan seluruh warga/ masyarakat di Desa Sikapak Barat. Program pengabdian ini berupa pemberian materi dengan metode ceramah, dan demonstrasi tentang personal hygiene yang berupa cuci tangan menggunakan sabun dan air mengalir sesuai dengan yang telah disampaikan sebelumnya. 


\section{Jurnal Abdimas Saintika}

Volume 3 Nomor 1 | https://jurnal.syedzasaintika.ac.id

Pada tahap pelaksanaan digunakan empat metode yaitu ceramah, tanya jawab, demonstrasi, dan praktik langsung. Metode ceramah bertujuan memberikan pengetahuan terkait dengan personal hygiene, tujuan mencuci tangan, manfaat mencuci tangan, indikasi waktu mencuci tangan, dan teknik mencuci tangan yang baik dan benar yaitu 6 langkah cuci tangan memakai sabun dan air mengalir. Metode tanya jawab bertujuan mengetahui penguasaan materi yang telah disampaikan melalui ingatan dan pengungkapan perasaan serta sikap masyarakat tentang yang dipelajari, dan didengar terkait dengan personal hygiene, tujuan mencuci tangan, manfaat mencuci tangan, indikasi waktu mencuci tangan, dan teknik mencuci tangan yang efektif yaitu 6 langkah cuci tangan memakai sabun dan air mengalir. Metode demonstrasi bertujuan memberikan pengalaman belajar melalui perbuatan melihat dan mendengarkan diikuti dengan meniru pekerjaan yang didemonstrasikan terkait dengan 6 langkah cuci tangan memakai sabun dan air mengalir. Metode praktik bertujuan memberikan kesempatan berlatih kepada warga untuk meningkatkan keterampilan sebagai penerapan bahan/ pengetahuan yang telah dipelajari sebelumnya mencapai tujuan dari pengajaran yang telah disampaikan, yaitu praktik 6 langkah cuci tangan memakai sabun dan air mengalir.

Untuk itu tujuan dari pengabdian kepada masyarakat yang dilakukan yaitu untuk meningkatkan pengetahuan dan keterampilan masyarakat dalam hal personal hygiene mencuci tangan menggunakan sabun dan air mengalir. Dengan sosialisasi melalui kegiatan pengabdian kepada masyarakat ini, diharapkan bisa memberi perubahan perilaku yang lebih baik kepada masyarakat dalam melalukan personal hygiene yaitu mencuci tangan dengan baik dan benar.

Jurnal Abdimas Saintika
Pengetahuan seseorang bisa menjadi lebih luas dengan memiliki sumber informasi yang lebih banyak, seseorang akan cenderung untuk mendapatkan informasi, baik dari orang lain maupun dari media massa. Semakin banyka pengetahuan yang dimiliki maka akan mempengaruhi praktik dari masyarakat tersebut. Demikian sebaliknya apabila peserta kegiatan pengabdian kepada masyarakat memiliki pengetahuan yang rendah, akan menghambat perkembangan praktik dalam memperoleh informasi baru (Wawan dan Dewi, 2010). Pendidikan kesehatan melalui pemberian materi tentang kesehatan merupakan upaya untuk mempengaruhi dan mengajak orang lain baik individu, kelompok, atau masyarakat agar melaksanakan cuci tangan yang baim dan benar. Diharapkan melalui pemberian materi terkait dengan personal hygiene yaitu tujuan mencuci tangan, manfaat mencuci tangan, indikasi waktu mencuci tangan, dan teknik mencuci tangan yang efektif yaitu 6 langkah cuci tangan memakai sabun dan air mengalir dapat mengubah perilaku masyarakat di Desa Sikapak Barat, Kecamatan Pariaman Utara, Kota Pariaman dari perilaku negatif mengarah ke perilaku yang positif. Untuk mencapai perilaku positif terdapat beberapa faktor yang mempengaruhi proses perubahan tersebut, sesuai dengan teori Green (1980) dalam Notoadmodjo, 2012, yaitu predisposing factors, enabling factors, dan reinforcing factors. Selain itu, sesuai dengan teori Rogers (1995) dalam Notoadmodjo (2012), proses perubahan perilaku juga didahului oleh perubahan pengetahuan, pengetahuan sikap atau persuasi, pengambilan keputusan, sehingga pada akhirnya akan tercapai tahap implementasi dan konfirmasi.

Dari hasil analisis data tentang kegiatan pengabdian kepada masyarakat didapatkan bahwa pengetahuan dan 


\section{Jurnal Abdimas Saintika}

Volume 3 Nomor $1 \mid$ https://jurnal.syedzasaintika.ac.id

praktik peserta kegiatan pengabdian kepada masyarakat mengalami peningkatan setelah mendapatkan materi menggunakan metode ceramah dan demonstrasi. Hal tersebut menunjukkan adanya pengaruh yang signifikan berupa peningkatan pengetahuan dan praktik peserta kegiatan pengabdian kepada masyarakat . Sebelum diberikan dengan metode ceramah dan demonstrasi cuci tangan sebagian besar peserta berpengetahuan dan berketerampilan kurang, setelah dilakukan intervensi dan implementasi dalam bentuk ceramah dan demonstrasi terjadi peningkatan pengetahuan yang sangat signifikan, begitu juga dengan praktik oleh masyarakat dalam kegiatan cuci tangan dengan menggunakan sabun dan air mengalir.

Pengetahuan peserta sebagian besar setelah dilakukan kegiatan pengabdian kepada masyarakat yaitu pengetahuan peserta menjadi pengetahuan baik. Hal ini sejalan dengan penelitian Hidayati, Salawati dan Istiana (2015) yang menyatakan bahwa metode demonstrasi lebih mudah untuk menunjukkan pengertian, ide, dan prosedur tentang suatu hal yang pernah dipersiapkan dengan teliti untuk memperlihatkan bagaimana cara melaksanakan suatu tindakan adegan dengan menggunakan alat peraga.

\section{DAFTAR PUSTAKA}

Ambarwati, Eny dkk. 2009. KDPK Kebidanan Teori dan Aplikasi. Jogjakarta : Nuha Medika.

Departemen Kesehatan RI. (2011). Cuci Tangan PakaiSabun Dapat Mencegah Berbagai Penyakit. Jakarta.

Dewi dan Wawan. 2010. Teori Pengukuran Pengetahuan Sikap dan Perilaku Manusia. Yogyakarta: Nuha Medika.

Jurnal Abdimas Saintika
Praktik masyarakat mengalami peningkatan dari kurang menjadi baik setelah dilakukan demonstrasi. Dengan dilakukan pemberian materi terkait dengan personal hygiene terutama mencuci tangan, tujuan mencuci tangan, manfaat mencuci tangan, indikasi waktu mencuci tangan, dan demonstrasi teknik mencuci tangan yang baik dan benar yaitu 6 langkah mencuci tangan memakai sabun dan air mengalir diharapkan masyarakat memahami tujuan dari pemberian materi yaitu masyarakat mampu memahami dan mempraktikkan tentang cara mencuci tangan dengan baik dan benar sehingga dapat menjadikannya sebagai perilaku dalam kehidupan seharihari.

\section{SIMPULAN}

Kegiatan penyuluhan upaya meningkatkan kesadaran mencuci tangan dilaksanakan pada hari Sabtu dan Minggu, tanggal 3-4 April 2021 di Desa Sikapak Barat berjalan dengan lancar mulai sosialisasi, pengetahuan dan demonstrasi, serta tahap evaluasi. Seluruh masyarakat antusias dalam mengikuti kegiatan, dimana terlihat dari benyaknya pertanyaan yang mereka ajukan. Kegiatan ini efektif dilakukan dalam peningkatan pengetahuan masyarakat, terlihat adanya peningkatan siswa sebelum dan sesudah mendapatkan penyuluhan yang terlihat dari koesioner pre dan post test.

Depkes RI. (2009). Panduan Penyelenggaraan Hari Cuci Tangan Pakai Sabub Sedunia (CTPS). Jakarta : Depkes RI

Fitriasari, D.N. dan Syaifudin. (2011). Hubungan Perilaku Mencuci Tangan Menggunakan Sabun Dengan Kejadian Diare Pada Anak Usia Pra Sekolah di Dusun 10 Pandowan Brosot Galur Kulon Progo. Naskah Publikasi. Yogyakarta : Program Studi Ilmu 


\section{Jurnal Abdimas Saintika}

Keperawatan. Sekolah Tinggi Ilmu Kesehatan "Aisyiyah. hal. 1-11.

Hadiyanto, H. (2016). Perilaku Hidup Bersih dan Sehat (PHBS) Tatanan Keluarga Di Posdaya Al-Fadilah. Jurnal Surya : Seri Pengabdian kepada Masyarakat, 2 (1), hal. 8992.

Kemenkes RI. 2010. Pedoman perilaku hiudp bersih dan sehat. Jakarta : Kementrian Kesehatan Republik Indonesia.

Kemenkes. (2011). Cuci Tangan Pakai Sabun, Perilaku Sederhana Berdampak Luar Biasa. Jakarta.

Kementrian Kesehatan RI. (2012). Pedoman Pengendalian Cacingan. Direktorat jenderal PP dan PL.

Kemenkes RI. (2014). Profil Kesehatan Indonesia. Jakarta : Kementerian Kesehatan Republik Indonesia.

Listyorini, W. (2012). Hubungan Antara Kebiasaan Mencuci Tangan Anak Pra Sekolah Dengan Kejadian Diare Di Wilayah Kerja Puskesmas Pajang Surakarta. Naskah Publikasi. Universitas Muhammadiyah Surakarta.

Notoatmodjo, S. 2012. Pendidikan dan Perilaku Kesehatan. Jakarta:PT Rineka Cipta.

RI, D. (2007). Pedoman Untuk Tenaga Kesehatan Usaha Kesehatan Sekolah Di Tingkat Sekolah Dasar. Jakarta.

Sariwati, A. Shofi, M., Badriyah, L. (2019). Pelatihan Pemanfaatan Limbah Botol Plastik Sebagai Media Pertumbuhan Tanaman Hidroponik. Journal of Community Enggagement and Empowerment 1(1). Hal. 6-13.

Setyaningrum, R., Rofi'i, A., \& Setyanti, A. (2016). Tingkat Pengetahuan Dan Sikap Tentang Cuci Tangan Pakai Sabun (CTPS) Pada Siswa SDN Batuah I Dan Batuah III
Pagatan. Jurnal Berkala Kesehatan, 1(1).

Silitonga, M. M., Sudharmono, U., \& Hutasoit, M. (2009). Prevalensi Kecacingan Pada Murid Sekolah Dasar Negeri Di Desa Cihanjuang Rahayu Parongpong Bandung Barat. Majalah Kedokteran Bandung, 41(2).

Siswanto, Hadi, 2010. Pendidikan Kesehatan Anak Usia Dini. Yogyakarta: Pustaka Rihama.

Shofi, M. (2019). Pemberdayaan Anggota PKK Melalui Pembuatan Lilin Aromaterapi. Journal of Community Enggagement and Empowerment 1(1). Hal. 40-46.

Utomo, A. M., \& Alfiyanti, D. (2013). Hubungan Perilaku Cuci Tangan Pakai Sabun (CTPS) Dengan Kejadian Diare Anak Usia Sekolah Di SDN 02 Pelemsengir Kecamatan Todanan Kabupaten Blora. FIKkeS, 6(1)

WHO. (2009). Guidelines on Hand Hygiene in Healthcare. Geneva. 